\title{
DESKRIPSI DAN ANALISIS PENYEBARAN PENYAKIT MERS MELALUI SISTEM REAKSI DIFUSI
}

\author{
Syamsyida Rozi \\ Program Studi Sistem Komputer, \\ Sekolah Tinggi Ilmu Komputer Dinamika Bangsa, Jambi, Indonesia \\ e-mail: syamsyida.rozi@gmail.com
}

\begin{abstract}
Abstrak. Penelitian ini diadakan berkaitan dengan mewabahnya penyakit Mers di kawasan Timur Tengah sejak 2012, bahkan mewabah hingga ke Korea pada 2015. Hingga Desember 2017, WHO masih menerima laporan terjadinya kasus baru Mers di beberapa negara mengingat hingga saat ini belum ada vaksin untuk mencegah manusia dari virus Mers. Berdasarkan data WHO, hingga Desember 2017 telah terjadi 2.122 kasus Mers dan hampir 35\% dari total kasus tersebut dinyatakan meninggal. Oleh karena itu, pada artikel ini, dibentuk model matematika berbentuk persamaan reaksi difusi dan kinetik berupa sistem Persamaan Diferensial Parsial (PDP) berkenaan dengan penyebaran virus Mers pada populasi manusia di daerah epidemi yang melibatkan tindakan karantina terhadap individu yang terinfeksi Mers. Kemudian keberadaan solusi traveling wave dari sistem tersebut diinvestigasi dan kecepatan penyebaran virusnya dianalisa. Berdasarkan sistem dan nilai parameter yang digunakan, diperoleh besaran basic reproduction number, $R_{0}=2,2$ yang menunjukkan bahwa Mers menjadi epidemi di populasi, dan diperoleh kecepatan minimum penyebaran Mers sebesar 2,09 $\mathrm{km} / \mathrm{hari}$. Melalui analisa sensitifitas kecepatan dan gelombang traveling wave, diperoleh kesimpulan bahwa untuk mengontrol laju penyebaran virus Mers, maka sangat perlu mengkarantina individu yang terindikasi virus Mers segera. Keberadaan solusi traveling wave dari sistem dapat ditunjukkan melalui simulasi numerik dengan metode FTCS (Forward Time Center Space).
\end{abstract}

Kata kunci: Mers, persamaan difusi, persamaan diferensial parsial, traveling wave, kecepatan minimum.

\begin{abstract}
This research is conducted related to the outbreak of Mers disease in Middle East since 2012 and even became outbreak also in Korea in 2015. In fact, as of December 2017, there is still new case of Mers infection which reported to WHO as there is no vaccine yet to avoid human from the virus. Based on data from WHO, as many as 2,122 cases of Mers have happened as of December 2017 and about $35 \%$ of total cases have been died. Due to that, in this article, the mathematical model with the form of reaction diffusion and kinetic equations in system of partial differential equations (PDE) is created, related to the Mers disease spreading in human population in epidemic area which involve quarantine action to the infected individual. Then, the existence of traveling wave solution of the sistem is investigated and the speed of virus spreading is analyzed. Based on the sistem and value of parameters used, it's obtained that the value of basic reproduction number, $R_{0}=2.2$ which means that Mers becomes epidemic in population. Besides, it is also obtained that the minimum wave speed is $2.09 \mathrm{~km} /$ day. Through the sensitivity analysis of wave speed, the conclusion is that it is necessary to quarantine the infected individual soon to control the speed of Mers spreading. The traveling wave solution finally can be performed through numerical simulation by using FTCS (Forward Time Center Space) method.
\end{abstract}

Keywords: Mers, diffusion equation, partial differential equations, traveling wave, minimum speed.

\section{Pendahuluan}

Penyakit Mers (Middle East respiratory syndrome) adalah suatu penyakit pernafasan yang disebabkan oleh virus yang dikenal dengan nama Mers-CoV (Middle East respiratory syndrome coronavirus). Penamaan virus dan penyakit tersebut disepakati oleh Coronavirus Study Group (CSG) of the International Committee on Taxonomy of Viruses sesuai dengan 
lokasi mewabahnya penyakit ini, yaitu di kawasan Timur Tengah (de Groot et al., 2013). Berdasarkan penelitian, Mers-CoV sepertinya merupakan zoonotic virus yang memasuki populasi manusia di Semenanjung Arab melalui kontak langsung ataupun tidak langsung dengan unta ataupun produk-produk dari unta (misalnya susu unta dan daging unta). Namun demikian, individu manusia yang terinfeksi virus ini kemudian dapat menularkan virus ke individu lainnya. Bahkan kasus-kasus baru berkaitan dengan Mers didominasi oleh penularan dari manusia ke manusia. Infeksi Mers-CoV memasuki populasi manusia pertama kali pada April 2012 di Jordan, yang kemudian mewabah di kawasan Semenanjung Arab dengan cepat ketika itu. Kemudian pada tahun 2015, penyakit ini mewabah di Korea setelah seorang warga Korea melakukan perjalanan ke Saudi Arabia. Orang yang terinfeksi Mers-CoV biasanya mengalami gejala demam, batuk-batuk, susah bernafas, infeksi saluran pernafasan akut seperti pneumonia dan beberapa orang mengalami gagal ginjal. Median umur orang yang terserang infeksi Mers-CoV adalah 50 tahun yang didominasi oleh pria (CDC, 2016). Berdasarkan penelitian, orang yang paling beresiko terinfeksi Mers adalah orang yang bermukim dekat peternakan unta atau berinteraksi dengan unta yang telah terinfeksi, orang yang tinggal di rumah ataupun lingkungan yang sama dengan penderita Mers dan orang yang bekerja di tempat pelayanan kesehatan yang melayani penderita yang memiliki gejala penyakit Mers (WHO, 2017).

Berdasarkan informasi yang dipublikasikan oleh World Health Organization (WHO), sejak tahun 2012 hingga Desember 2017, telah terdeteksi 2.122 kasus Mers yang dilaporkan ke WHO, termasuk di dalamnya 740 orang meninggal (hampir 35\% dari total kasus) yang tersebar di 27 negara. Sekitar 80\% kasus Mers terjadi di kawasan Arab Saudi. Hingga saat ini, kasus Mers masih ditemukan dan dilaporkan ke WHO. WHO juga menyatakan bahwa belum ada vaksin untuk mencegah penularan Mers-CoV (WHO, 2017). Hal ini menjadi pemicu penelitian ini, yaitu mendeskripsikan proses penularan dan penyebaran penyakit Mers ke dalam sistem matematika untuk menginvestigasi secara matematis upaya efektif pencegahan penyebaran penyakit Mers supaya tidak terjadi pandemik. Faktor yang ditekankan pada sistem adalah adanya tindakan karantina/ isolasi terhadap individu yang terindikasi Mers-CoV.

\section{Metode Penelitian}

Penelitian ini mempertimbangkan bahwa pergerakan virus Mers diasumsikan sebagai akibat dari pergerakan individu-individu pada populasi, sehingga sistem penyebaran penyakit Mers yang dibentuk akan melibatkan koefisien difusi untuk memperoleh sistem persamaan reaksi difusi dan kinetik yang berbentuk Persamaan Diferensial Parsial (PDP). Bentuk umum dari sistem difusi yang melibatkan reaksi kinetik adalah:

$$
\frac{\partial u}{\partial t}=D \frac{\partial^{2} u}{\partial x^{2}}+f(u)
$$

dengan $D \frac{\partial^{2} u}{\partial x^{2}}$ menunjukkan reaksi difusi, $f(u)$ menunjukkan reaksi kinetik dan $u$ tergantung pada $x$ dan $t$. Koefisien difusi $(D)$ merupakan suatu ukuran bagaimana seseorang berpindah dengan efisien dari satu daerah ke daerah lainnya, yang memiliki satuan panjang ${ }^{2} /$ waktu (Murray, 2002).

Analisa dinamik (titik keseimbangan beserta stabilitasnya) dari sistem PDP dimulai dengan menganalisa sistem Persamaan Diferensial Biasa (PDB) yang diperoleh dengan mengabaikan suku difusi. Titik keseimbangan dari sistem PDB merupakan akar-akar dari 
persamaan yang diperoleh setelah menetapkan fungsi-fungsi di ruas kanan pada sistem bernilai 0 (Boyce \& DiPrima, 2012). Titik keseimbangan bersifat stabil jika semua bagian riil dari nilai eigennya bernilai negatif dan bersifat tidak stabil jika terdapat bagian riil dari nilai eigennya yang bernilai positif (Boyce \& DiPrima, 2012). Pada tahap ini dapat ditemukan basic reproduction number $\left(R_{0}\right)$ untuk mengetahui apakah Mers menjadi epidemi populasi atau tidak. Menurut (Diekmann \& Heesterbeek, 2000), $R_{0}$ adalah rata-rata kasus infeksi baru yang disebabkan oleh satu individu yang terinfeksi pada masa menularnya dalam suatu populasi yang memuat individu susceptible. $R_{0}>1$ berarti individu yang terinfeksi pada kasus kedua lebih banyak dari pada kasus sebelumnya sehingga terjadi epidemi pada populasi. Sedangkan $R_{0}<1$ berarti tidak terjadi epidemi pada populasi. Salah satu cara untuk memperoleh nilai $R_{0}$ menurut Diekmann dkk dalam (Diekmann et al., 2010) adalah dengan metode Next Generation Matrix (NGM) with large domain dengan langkah sebagai berikut:

1) Mengambil persamaan-persamaan yang menggambarkan kasus infeksi baru dan perubahan dalam kelas/ kompartemen infeksi dari sistem PDB. Selanjutnya persamaanpersamaan ini disebut sebagai subsistem infeksi,

2) Melakukan linierisasi subsistem infeksi di sekitar titik keseimbangan bebas penyakit yang dituliskan dalam bentuk matriks dan disebut dengan matriks Jacobian,

3) Mendekomposisikan matriks Jacobian dari subsistem infeksi sebagai $T+\Sigma$, dengan $T$ merupakan matriks transmisi yang elemen-elemennya berhubungan dengan proses penularan infeksi. Sedangkan $\Sigma$ merupakan matriks transisi yang elemen-elemennya berhubungan dengan perpindahan kelas/ kompartemen, termasuk kematian.

4) Menemukan NGM with large domain $\left(K_{L}\right)$, yaitu $K_{L}=-T \Sigma^{-1}$,

5) Menemukan nilai eigen dominan dari matriks $K_{L}$ dan selanjutnya nilai eigen dominan tersebut dinyatakan sebagai $R_{0}$.

Dalam sistem yang melibatkan reaksi difusi, traveling wave dan kecepatan gelombang adalah hal yang menarik untuk dibahas. Menurut (Murray, 2002), traveling wave merupakan suatu gelombang yang berjalan dengan kecepatan tetap tanpa ada perubahan bentuk gelombang untuk setiap waktu. Untuk menemukan kecepatan gelombang, maka sistem PDP ditransformasi menjadi PDB dengan mentransformasi $(x, t)$ menjadi variabel gelombang $z$ dengan $z=x+c t$, dan $c$ merupakan kecepatan gelombang traveling wave, sehingga dengan $u(x, t)=U(z)$, maka

$$
\begin{gathered}
\frac{\partial u}{\partial t}=\frac{d U}{d z} \cdot \frac{\partial z}{\partial t}=\frac{d U}{d z} \cdot c=c \cdot \frac{d U}{d z} \\
\frac{\partial u}{\partial x}=\frac{d U}{d z} \cdot \frac{\partial z}{\partial x}=\frac{d U}{d z} \cdot 1=\frac{d U}{d z} \Longrightarrow \frac{\partial^{2} u}{\partial x^{2}}=\frac{d^{2} U}{d x^{2}} .
\end{gathered}
$$

Dengan mensubstitusi formula ini ke persamaan (1), maka persamaan (1) ditulis menjadi

$$
c \frac{d U}{d z}=D \frac{d^{2} U}{d z^{2}}+f(U) .
$$

Dalam terminologi sistem dinamik, solusi traveling wave menghubungkan titik keseimbangan yang tidak stabil ke titik keseimbangan yang stabil (Murray, 2002). Menurut Liu (Liu et al., 2013), dalam model epidemi, traveling wave difokuskan pada solusi yang menghubungkan titik keseimbangan bebas penyakit yang tidak stabil ke titik keseimbangan endemik yang stabil, sehingga untuk menginvestigasi solusi traveling wave, titik 
keseimbangan endemik harus ada. Dalam (Diekmann et al., 2010), Diekmann mengungkapkan bahwa titik keseimbangan endemik ada jika nilai $R_{0}>1$.

Solusi traveling wave dari PDP ditampilkan melalui simulasi numerik menggunakan Matlab dengan salah satu metode finite difference, yaitu metode FTCS (Forward Time Center Space). Jika dipilih mesh size $\Delta x$ sedemikian $x=j \Delta x$ dan $\Delta t$ sedemikian $t=n \Delta t$, dan kemudian $u(x, t) \equiv u(j \Delta x, n \Delta t)$ dinotasikan dengan $u_{j}^{n}$, maka aproksimasi untuk turunan pertama terhadap $t$ dilakukan dengan metode forward difference dan aproksimasi untuk turunan kedua terhadap $x$ dengan metode center space, sehingga persamaan difference untuk persamaan (1) adalah

$$
\frac{u_{j}^{n+1}-u_{j}^{n}}{\Delta t}=D \frac{u_{j+1}^{n}-u_{j}^{n}+u_{j-1}^{n}}{(\Delta x)^{2}}+f\left(u_{j}^{n}\right) .
$$

Dengan demikian $u_{j}^{n+1}$ dapat ditemukan sebagai berikut

$$
u_{j}^{n+1}=u_{j}^{n}+\frac{D \cdot \Delta t}{(\Delta x)^{2}}\left(u_{j+1}^{n}-2 u_{j}^{n}+u_{j-1}^{n}\right)+\Delta t . f\left(u_{j}^{n}\right) .
$$

Untuk menghindari error yang besar dan mempertahankan kestabilan solusi, maka $\Delta t$ dan $\Delta x$ dipilih sedemikian sehingga $0<\frac{\Delta t}{\Delta x^{2}}<\frac{1}{2}$ (Strauss, 2008). Pada artikel ini, untuk menghindari resiko ketidakstabilan solusi, maka dipilih $\Delta t$ dan $\Delta x$ sehingga $0<D \frac{\Delta t}{\Delta x^{2}}<\frac{1}{2}$.

Selanjutnya dilakukan analisis sensitifitas terhadap kecepatan penyebaran penyakit Mers untuk dapat menjadi rujukan demi mengontrol penyebaran penyakit tersebut. Analisis sensitifitas dilakukan karena adanya kemungkinan perubahan keadaan dilapangan sehingga nilai-nilai parameter yang mempengaruhi kecepatan penyebaran Mers berubah. Oleh karena itu analisis sensitifitas penyebaran Mers dilakukan dengan mengubah-ubah nilai parameter tersebut sesuai dengan kemungkinan yang dapat terjadi di lapangan dan ditampilkan dalam bentuk grafik, sehingga dapat diamati pada nilai parameter yang berapa/ bagaimana kecepatan penyebaran penyakit Mers akan meningkat atau menurun.

\section{Hasil penellitian dan pembahasan}

\section{Sistem Penyebaran Penyakit Mers dan analisis penyebaran penyakit Mers}

Populasi manusia diasumsikan dibagi kedalam 4 kelas, yaitu individu susceptible, individu terinfeksi Mers, penderita Mers yang dikarantina/ diisolasi dan individu recovered atau yang sembuh dari penyakit Mers. Banyaknya individu pada masing-masing kelas tersebut pada posisi $x$ dan waktu $t$ secara berturut-turut dinotasikan dengan $S(x, t), I(x, t)$, $Q(x, t)$, dan $R(x, t)$. Pada artikel ini, yang dimaksud dengan individu dikarantina adalah bahwa individu yang terinfeksi Mers diisolasi di suatu ruang tertutup dan steril di rumah sakit sambil memperoleh pengobatan terhadap gejala penyakit yang dirasakan oleh penderita. Setiap tenaga medis yang mengunjungi ruang isolasi harus menggunakan masker dan pakaian tertutup, bahkan menggunakan helm khusus ketika memberikan pengobatan terhadap pasien.

Pada sistem yang dibentuk, diasumsikan populasi di kelas $S$ berubah karena adanya rekrutmen individu sebesar $A$ dan ada individu terinfeksi Mers sehingga berpindah ke kelas $I$. Populasi di kelas $I$ berkurang karena adanya individu terinfeksi yang dikarantina sehingga berpindah ke kelas $Q$ sebanyak $\lambda I$, karena sembuh alami sehingga berpindah ke kelas $R$ sebanyak $\gamma_{1} I$ dan meninggal karena Mers sebanyak $m_{2} I$. Populasi di kelas $Q$ berkurang 
karena adanya individu yang sembuh sehingga berpindah ke kelas $R$ sebanyak $\gamma_{2} Q$ dan meninggal karena Mers sebanyak $m_{3} Q$. Ketika individu sudah berada di kelas $R$, maka selamanya individu tersebut tetap berada di kelas tersebut. Selain itu, populasi di masingmasing kelas akan berkurang karena kematian alami. Karena diisolasi di suatu ruang tertutup dan tidak melakukan perpindahan, maka suku difusi tidak terdapat pada persamaan perubahan populasi di kelas $Q$. Berdasarkan asumsi tersebut, maka sistem difusi penyebaran Mers yang berbentuk sistem persamaan diferensial parsial adalah:

$$
\begin{aligned}
& \frac{\partial S}{\partial t}=D \frac{\partial^{2} S}{\partial x^{2}}+A-\beta S I-m_{1} S, \\
& \frac{\partial I}{\partial t}=D \frac{\partial^{2} I}{\partial x^{2}}+\beta S I-\lambda I-\gamma_{1} I-m_{1} I-m_{2} I, \\
& \frac{\partial Q}{\partial t}=\lambda I-\gamma_{2} Q-m_{1} Q-m_{3} Q, \\
& \frac{\partial R}{\partial t}=D \frac{\partial^{2} R}{\partial x^{2}}+\gamma_{1} I+\gamma_{2} Q-m_{1} R,
\end{aligned}
$$

dengan $t$ dalam hari, $x$ dalam $\mathrm{km}$, dan $D$ dalam $\mathrm{km}^{2} /$ hari. Semua nilai parameter pada sistem (2) bernilai riil positif.

Untuk mengamati dinamik dari sistem (2), terlebih dulu diamati dinamik dari sistem tanpa reaksi difusi yang berbentuk sistem PDB orde 1 :

$$
\begin{aligned}
& \frac{d S}{d t}=A-\beta S I-m_{1}, \\
& \frac{d I}{d t}=\beta S I-\lambda I-\gamma_{1} I-m_{1} I-m_{2} I, \\
& \frac{d Q}{d t}=\lambda I-\gamma_{2} Q-m_{1} Q-m_{3} Q, \\
& \frac{d R}{d t}=\gamma_{1} I+\gamma_{2} Q-m_{1} R .
\end{aligned}
$$

\begin{tabular}{|c|c|c|c|}
\hline Simbol & Definisi & Nilai & Satuan \\
\hline$A$ & Laju rekruitmen pada populasi & 1000 & individu/hari \\
\hline$\beta$ & $\begin{array}{l}\text { Laju transmisi virus yang sukses ditularkan dari } \\
\text { individu terinfeksi ke individu susceptible }\end{array}$ & 0,00002 & $\begin{array}{l}\text { 1/(hari- } \\
\text { individu) }\end{array}$ \\
\hline$m_{1}$ & Laju kematian alami individu & 0,01 & 1/hari \\
\hline$m_{2}$ & $\begin{array}{l}\text { Laju kematian penderita Mers yang tidak dikarantina } \\
\text { dan tidak memperoleh pengobatan medis }\end{array}$ & 0,3 & $1 /$ hari \\
\hline$m_{3}$ & $\begin{array}{l}\text { Laju kematian individu yang dikarantina karena } \\
\text { terinfeksi Mers }\end{array}$ & 0,1 & $1 /$ hari \\
\hline$\lambda$ & $\begin{array}{l}\text { Tingkat tindakan karantina terhadap individu } \\
\text { terinfeksi Mers }\end{array}$ & 0,4 & 1/hari \\
\hline$\gamma_{1}$ & Laju kesembuhan alami individu yang terinfeksi & 0,2 & 1/hari \\
\hline
\end{tabular}

Total populasi manusia adalah $N(t)=S(t)+I(t)+Q(t)+R(t)$. Jika tidak ada individu di kelas $I$ dan $Q$ meninggal karena Mers $\left(m_{2}=m_{3}=0\right)$, maka $N=A / m_{1}$ untuk $t \rightarrow \infty$. Dengan demikian total populasi terbatas di atas pada $A / m_{1}$. Analisis dan investigasi tentang penyebaran Mers yang dibahas pada artikel ini dibatasi untuk daerah Arab Saudi sebagai tempat Mers menjadi endemik, sehingga pada artikel ini digunakan nilai parameter pada Tabel 1.

Tabel 1. Nilai parameter 
Mers

$\gamma_{2} \quad$ Laju kesembuhan individu yang dikarantina karena $\quad 0,3 \quad 1 /$ hari terinfeksi Mers

$\begin{array}{lll}\text { Koefisien difusi } & 1 & \mathrm{Km}^{2} / \mathrm{hari}\end{array}$

Sistem (3) memiliki 2 titik keseimbangan yaitu:

1) Titik keseimbangan bebas penyakit, $E_{0}=\left(S^{*}, I^{*}, Q^{*}, R^{*}\right)=\left(\frac{A}{m_{1}}, 0,0,0\right)$ yang berarti tidak ada individu yang terinfeksi Mers.

Basic reproduction number, $R_{0}$, diperoleh dengan pendekatan metode Next Generation Matrix $(N G M)$ with large domain, dengan subsistem infeksi

$$
\begin{aligned}
& \frac{d I}{d t}=\beta S I-\lambda I-\gamma_{1} I-m_{1} I-m_{2} I, \\
& \frac{d Q}{d t}=\lambda I-\gamma_{2} Q-m_{1} Q-m_{3} Q
\end{aligned}
$$

dan matriks

$$
K_{L}=\left[\begin{array}{cc}
\frac{\beta A}{m_{1}\left(\lambda+\gamma_{1}+m_{1}+m_{2}\right)} & 0 \\
0 & 0
\end{array}\right],
$$

sehingga diperoleh

$$
R_{0}=\frac{\beta A}{m_{1}\left(\lambda+\gamma_{1}+m_{1}+m_{2}\right)}
$$

Dengan melakukan linierisasi sistem (3) di sekitar $E_{0}$, maka diperoleh nilai eigen : $\sigma_{1}=\sigma_{2}=-m_{1}, \sigma_{3}=\left(\lambda+\gamma_{1}+m_{1}+m_{2}\right)\left(R_{0}-1\right)$ dan $\sigma_{4}=-\left(\gamma_{2}+m_{1}+m_{3}\right)$.

Jika $R_{0}<1$, maka semua nilai eigen tersebut bernilai negatif sehingga $E_{0}$ bersifat stabil asimptotik yang artinya penyakit Mers tidak menjadi epidemi pada populasi manusia. Sedangkan jika $R_{0}>1$, maka terdapat nilai eigen positif sehingga $E_{0}$ menjadi tidak stabil yang berarti penyakit Mers bisa menjadi epidemi pada populasi.

2) Titik keseimbangan $E_{1}=\left(S^{*}, I^{*}, Q^{*}, R^{*}\right)$, dengan $S^{*}=\frac{\lambda+\gamma_{1}+m_{1}+m_{2}}{\beta}, I^{*}=\frac{m_{1}}{\beta}\left(R_{0}-1\right)$, $Q^{*}=\frac{\lambda m_{1}}{\beta\left(\gamma_{2}+m_{1}+m_{3}\right)}\left(R_{0}-1\right)$ dan $R^{*}=\frac{\left[\gamma_{1} \gamma_{2}+\gamma_{1} m_{1}+\gamma_{1} m_{3}+\gamma_{2} \lambda\right]}{\beta\left(\gamma_{2}+m_{1}+m_{3}\right)}\left(R_{0}-1\right)$.

Titik $E_{1}$ disebut titik keseimbangan endemik, yang akan ada jika $R_{0}>1$.

Dengan melakukan linierisasi sistem (3) di sekitar titik $E_{1}$, maka diperoleh nilai eigen $\sigma_{1}=-\left(\gamma_{2}+m_{1}+m_{3}\right)<0, \sigma_{2}=-m_{1}<0$, dan $\sigma_{3}, \sigma_{4}$ diperoleh dari solusi dari persamaan kuadrat

$$
a_{0} \sigma^{2}+a_{1} \sigma+a_{2}=0
$$

dengan $a_{0}=\lambda+\gamma_{1}+m_{1}+m_{2}, a_{1}=\beta A, a_{2}=m_{1}\left(\lambda+\gamma_{1}+m_{1}+m_{2}\right)^{2}\left(R_{0}-1\right)$.

Jika $R_{0}>1$, maka $\sigma_{3} . \sigma_{4}>0$ dan $\sigma_{3}+\sigma_{4}<0$, sehingga $\sigma_{3}$ dan $\sigma_{4}$ memiliki bagian rill negatif. Dengan demikian jika $R_{0}>1$, maka titik $E_{1}$ ada dan titik ini bersifat stabil yang berarti penyakit Mers cendrung akan menjadi epidemi pada populasi. 
Berdasarkan nilai parameter pada Tabel 1, yang kemudian disubstitusi ke formula $R_{0}$ pada persamaan (4), maka diperoleh $R_{0}=2,2>1$, sehingga terdapat 2 titik keseimbangan yaitu titik $E_{0}$ yang tidak stabil dan titik $E_{1}$ yang stabil yang berarti terjadi epidemi pada populasi. Hal ini ditunjukkan pula pada phase portrait yang ditampilkan pada Gambar 1b), bahwa trajektori (himpunan solusi) dari sistem (3) dengan nilai awal di sembarang titik terlihat menjauhi titik $E_{0}$ (bebas penyakit) dan menuju titik $E_{1}$ (endemik). Dan perubahan populasi di masing-masing kelas individu hingga hari ke-300 ditampilkan pada Gambar 1a) sebagai solusi dari sistem (3).
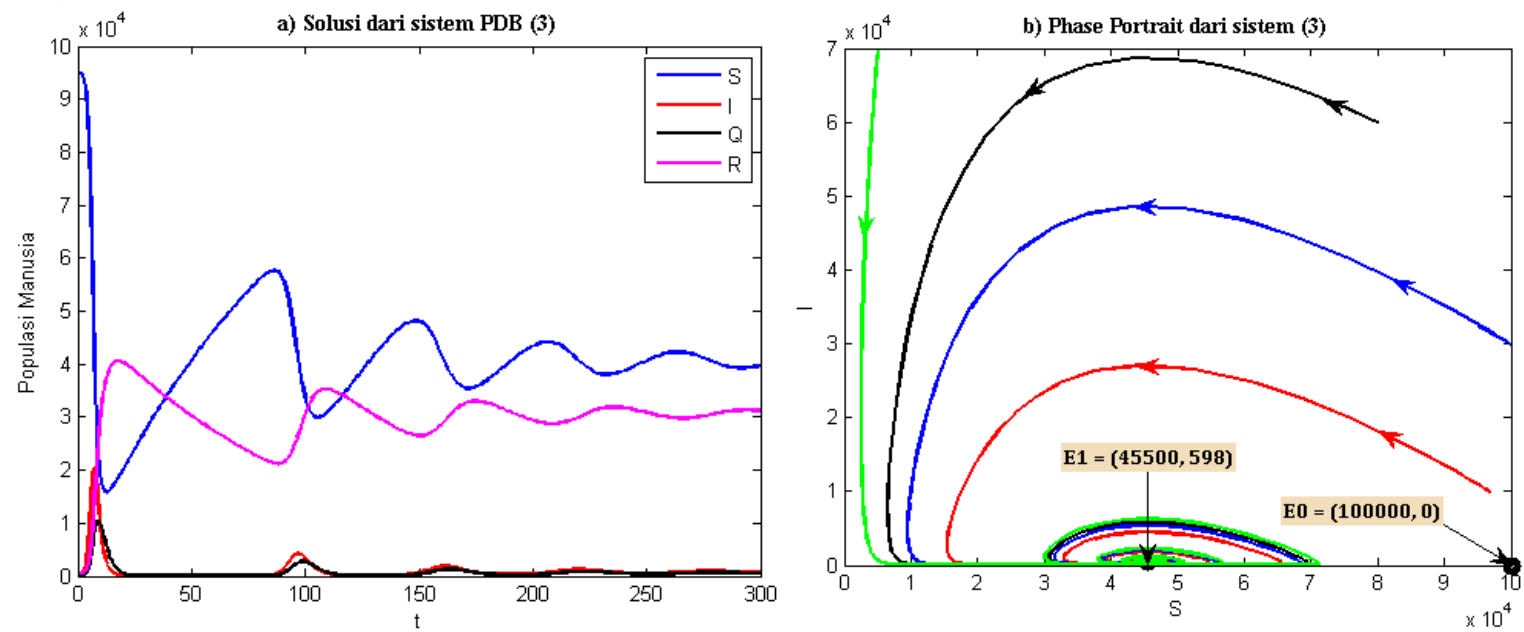

Gambar 1. a) Solusi dari sistem PDB (3). b) Phase portrait dari sistem (3) yang digambarkan pada bidang-SI untuk melihat perilaku dinamik dari sistem (3)

Dinamik dari sistem (3) di atas menjadi referensi untuk menganalisa dinamik dari sistem PDP (2). Untuk memperoleh solusi traveling wave dari sistem (2), maka kecepatan gelombang minimum harus ditemukan. Jika solusi traveling wave ada, maka solusi tersebut akan memenuhi kondisi

$$
(S(x, t), I(x, t), Q(x, t), R(x, t))=(\bar{S}(z), \bar{I}(z), \bar{Q}(z), \bar{R}(z))
$$

dengan $z=x+c t$ dan $c$ merupakan kecepatan gelombang yang nilainya tetap. Melalui transformasi ini, maka sistem (2) ditulis menjadi PDB

$$
\begin{aligned}
& \frac{d S}{d z}=y_{1}, \\
& \frac{d y_{1}}{d z}=\frac{1}{D}\left(c y_{1}-A+\beta S I+m_{1} S\right), \\
& \frac{d I}{d z}=y_{2}, \\
& \frac{d y_{2}}{d z}=\frac{1}{D}\left(c y_{2}-\beta S I+\lambda I+\gamma_{1} I+m_{1} I+m_{2} I\right), \\
& \frac{d Q}{d z}=\frac{1}{c}\left(\lambda I-\gamma_{2} Q-m_{1} Q-m_{3} Q\right), \\
& \frac{d R}{d z}=y_{3}, \\
& \frac{d y_{3}}{d z}=\frac{1}{D}\left(c y_{3}-\gamma_{1} I-\gamma_{2} Q+m_{1} R\right) .
\end{aligned}
$$


Sistem (5) juga memiliki 2 titik keseimbangan $\left(S^{*}, y_{1}^{*}, I^{*}, y_{2}^{*}, Q^{*}, R^{*}, y_{3}^{*}\right)$, yaitu titik keseimbangan bebas penyakit $E_{0}^{*}=\left(\frac{A}{m_{1}}, 0,0,0,0,0,0\right)$ dan titik keseimbangan endemik $E_{1}^{*}=$ $\left(S^{*}, 0, I^{*}, 0, Q^{*}, R^{*}, 0\right)$ dengan $S^{*}, I^{*}, Q^{*}$ dan $R^{*}$ merupakan komponen-komponen yang sama pada $E_{1}$. Dengan nilai parameter pada Tabel 1 yang menyebabkan besaran $R_{0}>1$, maka dapat diasumsikan sistem (3) memenuhi syarat batas:

$$
(\bar{S}(-\infty), \bar{I}(-\infty), \bar{Q}(-\infty), \bar{R}(-\infty))=E_{0}^{*} \operatorname{dan}(\bar{S}(\infty), \bar{I}(\infty), \bar{Q}(\infty), \bar{R}(\infty))=E_{1}^{*} .
$$

Sebagaimana yang dijelaskan pada (Murray, 2003) dan oleh Liu (Liu et al., 2013) bahwa untuk menginvestigasi kecepatan traveling wave, maka matriks Jacobian dari sistem (5) di sekitar titik keseimbangan bebas penyakit harus dipastikan memiliki nilai eigen yang semuanya bernilai riil dan minimal terdapat satu nilai eigen bernilai riil positif, sehingga solusi dari sistem (5) menjauhi titik keseimbangan bebas penyakit dengan cara tidak berosilasi. Jika terdapat nilai eigen bilangan kompleks (terutama memiliki bagian riil positif), maka solusi akan menjauhi titik keseimbangan bebas penyakit dengan cara berosilasi, sehingga akan muncul solusi $\bar{S}(z), \bar{I}(z), \bar{Q}(z), \bar{R}(z)$ yang bernilai negatif. Sedangkan $\bar{S}(z), \bar{I}(z), \bar{Q}(z)$, dan $\bar{R}(z)$ menyatakan suatu populasi yang nilainya harus non-negatif supaya realistis. Dengan kata lain, jika terdapat nilai eigen bilangan kompleks, maka solusi yang diperoleh tidak realistis sehingga tidak ada kesimpulan yang bisa ditarik.

Matriks Jacobian dari sistem (5) di sekitar titik $E_{0}^{*}$ adalah

$$
\left[\begin{array}{ccccccc}
0 & 1 & 0 & 0 & 0 & 0 & 0 \\
\frac{m_{1}}{D} & \frac{c}{D} & \frac{\beta A}{D m_{1}} & 0 & 0 & 0 & 0 \\
0 & 0 & 0 & 1 & 0 & 0 & 0 \\
0 & 0 & -\frac{\left(R_{0}-1\right)\left(\lambda+\gamma_{1}+m_{1}+m_{2}\right)}{D} & \frac{c}{D} & 0 & 0 & 0 \\
0 & 0 & \frac{\lambda}{c} & 0 & -\frac{\left(\gamma_{2}+m_{1}+m_{3}\right)}{c} & 0 & 0 \\
0 & 0 & 0 & 0 & 0 & 0 & 1 \\
0 & 0 & -\frac{\gamma_{1}}{D} & 0 & -\frac{\gamma_{2}}{D} & \frac{m_{1}}{D} & \frac{c}{D}
\end{array}\right] .
$$

Dengan mempertimbangkan semua parameter dan kecepatan $(c)$ bernilai riil positif, maka nilai eigen dari matriks Jacobian tersebut adalah $\sigma_{1}=-\frac{\gamma_{2}+m_{1}+m_{3}}{c}$ yang bernilai riil negatif, $\sigma_{2}, \sigma_{3}, \sigma_{4}, \sigma_{5}=\frac{c \pm \sqrt{c^{2}+4 D m_{1}}}{2 D}$ yang dua diantaranya bernilai riil positif dan dua lainnya bernilai riil negatif, serta $\sigma_{6}, \sigma_{7}=\frac{c \pm \sqrt{c^{2}-4 D\left(R_{0}-1\right)\left(\lambda+\gamma_{1}+m_{1}+m_{2}\right)}}{2 D}$. Oleh karena itu, untuk memperoleh hasil/ solusi yang realistis, maka nilai $c$ harus ditemukan sedemikian sehingga diperoleh $\sigma_{6}$ dan $\sigma_{7}$ bernilai riil. Supaya $\sigma_{6}$ dan $\sigma_{7}$ bernilai riil, maka haruslah

$$
c \geq 2 \sqrt{D\left(R_{0}-1\right)\left(\lambda+\gamma_{1}+m_{1}+m_{2}\right)} \text {. }
$$

Batas nilai $c$, antara yang dapat memberikan nilai eigen kompleks dan nilai eigen riil, atau antara yang dapat memberikan solusi tidak realistis dan solusi yang realistis, dinyatakan sebagai kecepatan minimum gelombang $\left(c_{\min }\right)$ dari traveling wave, yaitu

$$
c_{\text {min }}=2 \sqrt{D\left(R_{0}-1\right)\left(\lambda+\gamma_{1}+m_{1}+m_{2}\right)} .
$$


Dengan mensubstitusi nilai parameter pada Tabel 1 ke formula (6), maka diperoleh $c_{\text {min }}=$ $2,09 \mathrm{~km} /$ hari. Hal ini menunjukkan bahwa kecepatan minimum penyebaran penyakit Mers adalah $2,09 \mathrm{~km} /$ hari. Sehingga untuk $c \geq c_{\min }=2,09$, maka diperoleh nilai eigen yang semuanya riil dan terdapat nilai eigen riil positif, sehingga titik $E_{0}^{*}$ bersifat tidak stabil (saddle node), yang artinya solusi akan menjauhi titik keseimbangan bebas penyakit dengan cara yang tidak berosilasi menuju titik keseimbangan endemik $E_{1}^{*}$.

Kecepatan penyebaran Mers bisa saja berubah jika nilai parameter yang mempengaruhi $c_{\min }$ berubah. Analisis sensitifitas berkaitan dengan kecepatan penyebaran penyakit Mers ini ditampilkan secara visual pada Gambar 2. Gambar 2 menampilkan sensitifitas perubahan kecepatan penyebaran Mers $\left(c_{\text {min }}\right)$, yang merupakan fungsi yang tergantung pada koefisien difusi $(D)$, untuk perubahan $\beta, \lambda, \gamma_{1}$ dan $m_{2}$. Kurva berwarna biru diperoleh menggunakan nilai parameter pada Tabel 1. Secara visual, Gambar 2a) menunjukkan bahwa semakin tinggi laju penularan infeksi $(\beta)$ dari individu terinfeksi ke individu susceptible, maka penyebaran Mers akan semakin cepat. Gambar 2b), c) dan d) menunjukkan bahwa penyebaran penyakit akan melambat jika tingkat tindakan karantina $(\lambda)$ yang dilakukan terhadap individu terinfeksi Mers semakin besar, laju kesembuhan individu $\left(\gamma_{1}\right)$ yang terinfeksi Mers makin besar dan kematian individu $\left(m_{2}\right)$ karena terinfeksi Mers makin besar. Gambar $2 \mathrm{~b}$ ) menunjukkan bahwa jika tidak ada individu yang dikarantina akibat terinfeksi Mers, maka kecepatan penyebaran Mers adalah 2,44 km/hari. Jika dilakukan karantina terhadap individu yang terinfeksi dengan laju 0,4/hari, maka kecepatan penyebaran Mers menurun sebesar 0,35 $\mathrm{km} /$ hari. Selanjutnya jika laju tindakan karantina terhadap individu terinfeksi Mers terus sebesar 50\% dari sebelumnya, maka kecepatan penyebaran Mers turun dengan rata-rata 14\%. Selain itu, Gambar 2 juga menunjukkan bahwa semakin besar koefisien difusi, maka kecepatan penyebaran penyakit Mers semakin tinggi. Hal ini menunjukkan bahwa semakin luas pergerakan difusi dari individu susceptible dan individu yang terinfeksi Mers, maka penyebaran penyakit Mers semakin cepat.


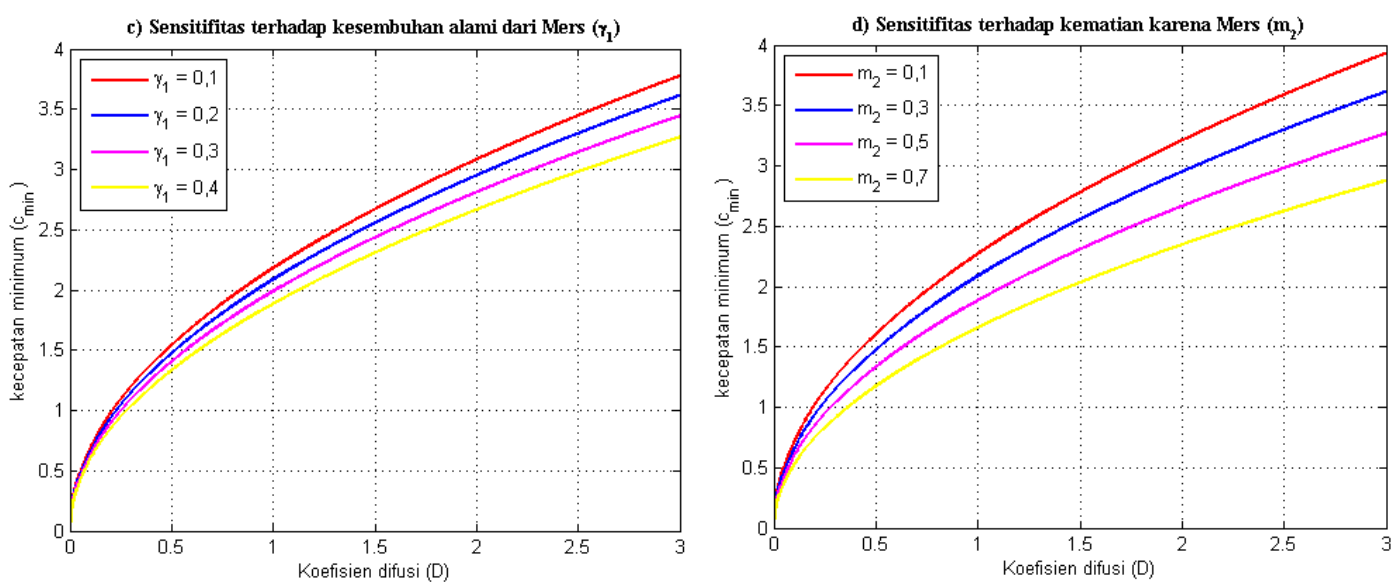

Gambar 2. Sensitifitas terhadap kecepatan penyebaran Mers karena perubahan beberapa nilai parameter.

Selanjutnya solusi traveling wave ditampilkan dengan pendekatan metode FTCS sebagaimana mana pada Gambar 3 dengan kondisi awal:

$x \in[0,50]$, berlaku $(S(x, 0), I(x, 0), Q(x, 0), R(x, 0))=E_{1}$,

$x \in[50,400]$, berlaku $(S(x, 0), I(x, 0), Q(x, 0), R(x, 0))=E_{0}$,

dengan $x$ memenuhi kondisi Neumann:

$$
\frac{\partial S}{\partial x}(L, t)=\frac{\partial I}{\partial x}(L, t)=\frac{\partial R}{\partial x}(L, t)=0, \quad L \in\{0,400\} .
$$

Solusi traveling wave ini ditampilkan dengan menggunakan nilai parameter pada Tabel 1. Supaya metode ini stabil, maka dipilih $\Delta t=0,2$ dan $\Delta x=0,1$.
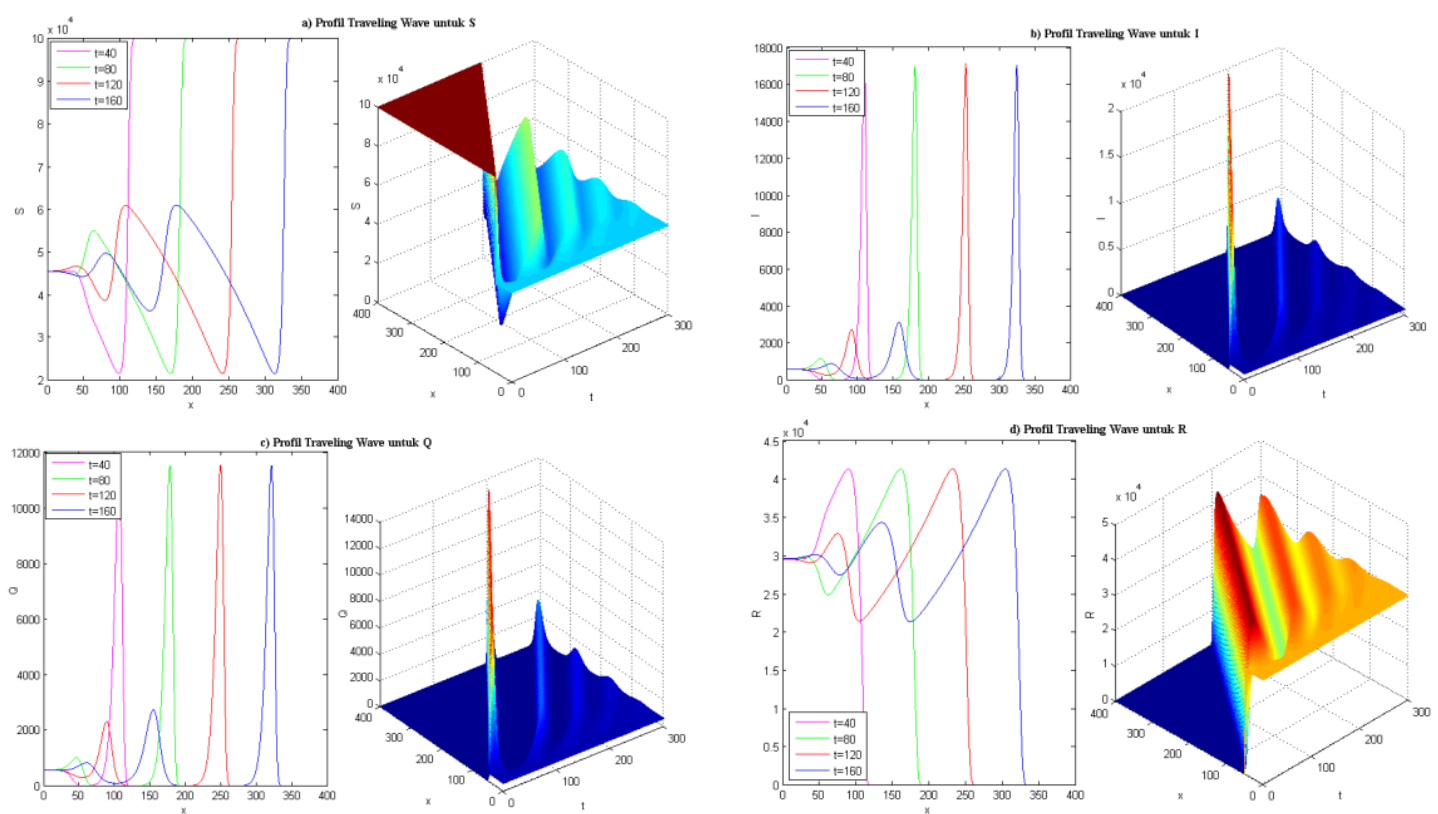

Gambar 3. Profil traveling wave untuk masing-masing kelas individu. Bagian kiri dari masing-masing gambar a), b), c), d) menunjukkan profil traveling wave yang ditampilkan pada bidang 2D. Bagian kanan menampilkan profil traveling wave pada ruang $3 \mathrm{D}$. 
Gelombang penyebaran Mers juga bisa berubah jika nilai parameter berubah sebagaimana yang diperlihatkan pada Gambar 4. Gelombang berwarna biru pada Gambar 4 diperoleh berdasarkan nilai parameter pada Tabel 1, sedangkan gelombang berwarna merah menunjukkan perubahan gelombang jika nilai $D, \lambda$, dan $\gamma_{1}$ diubah. Secara visual, Gambar 4a) menunjukkan koefisien difusi hanya mengubah kecepatan gelombang traveling wave, dan tidak mengubah populasi individu yang terinfeksi secara signifikan. Sedangkan dampak perubahan nilai parameter lainnya, seperti perubahan tingkat/ laju tindakan karantina terhadap individu terinfeksi $(\lambda)$ dan tingkat kesembuhan alami $\left(\gamma_{1}\right)$, sebagaimana yang ditampilkan pada Gambar 4b) dan c), selain mengubah kecepatan gelombang penyebaran Mers, tetapi juga mengubah ukuran gelombang, yaitu berkaitan dengan berubahnya populasi di kelas $I$. Gambar 4b) menunjukkan bahwa dengan meningkatkan laju tindakan karantina terhadap individu terinfeksi Mers, maka gelombang penyebaran Mers melambat, dan populasi individu yang terinfeksi juga semakin menurun. Gambar 4c) menunjukkan bahwa jika laju kesembuhan alami individu yang terinfeksi Mers meningkat, maka gelombang penyebaran Mers melambat dan populasi individu yang terinfeksi Mers menurun.

Berdasarkan analisis kecepatan dan ukuran gelombang, mengingat belum adanya vaksin untuk mencegah penularan dan penyebaran Mers, maka cara terbaik untuk mengontrol penyebaran Mers adalah dengan meningkatkan laju tindakan karantina terhadap individu yang terinfeksi Mers untuk meminimalisir dan sekaligus membatasi pergerakan individu tersebut.
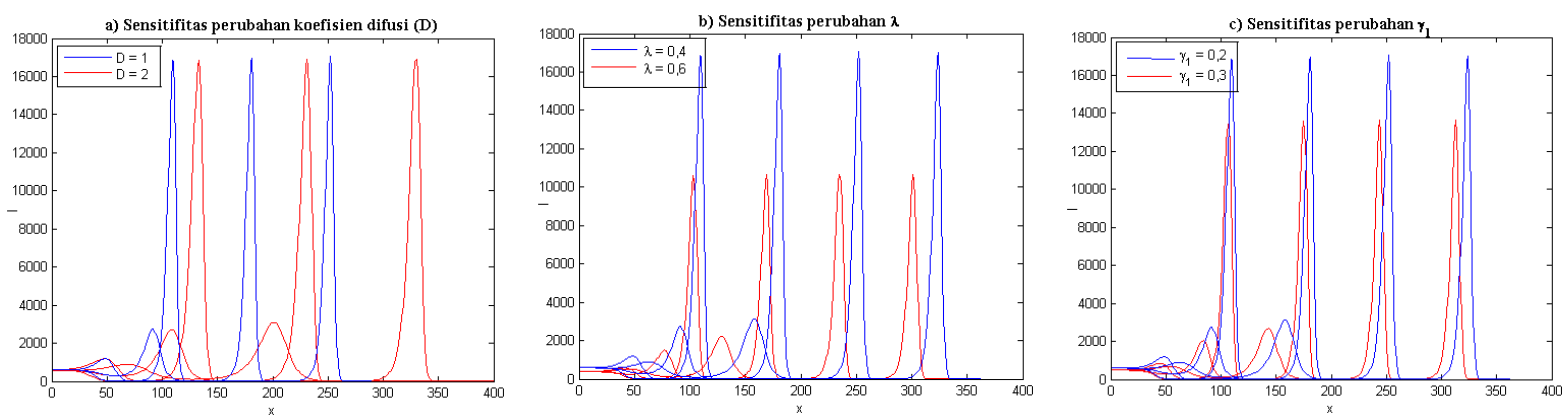

Gambar 4. Sensitifitas gelombang penyebaran Mers terhadap perubahan nilai parameter.

\section{Kesimpulan dan Saran}

Berdasarkan sistem difusi pada sistem (2) dan dengan nilai parameter pada Tabel 1, diperoleh nilai $R_{0}=2,2$ sehingga penyakit Mers menjadi epidemi pada populasi manusia, dengan kecepatan minimum penyebaran Mers adalah 2,09 km/ hari. Berdasarkan analisis sensitifitas kecepatan dan gelombang traveling wave sebagai solusi dari sistem (2) dapat disimpulkan bahwa untuk mengontrol penularan dan penyebaran penyakit Mers maka sangat penting untuk mengkarantina individu yang terinfeksi Mers dengan laju tinggi, sehingga pergerakan individu terinfeksi terbatas dan probabilitas penyebaran penyakit Mers semakin kecil. Mengkarantina individu yang terinfeksi Mers dengan laju tinggi, selain dapat mengontrol kecepatan penyebaran Mers, juga akan mencegah muncul kasus infeksi baru. Saran pada penelitian ini yang memerlukan penelitian berikutnya adalah melibatkan faktor penularan dari unta yang terinfeksi terhadap manusia, dikarenakan virus ini dikenal diawali berasal dari unta. 


\section{Daftar Pustaka}

Boyce, W. E., \& DiPrima, R. C. (2012). Elementary Differential Equations and Boundary Value Problems, Tenth Edition. John Wiley \& Sons, Inc.

CDC. (2017). MERS-CoV | Home | Middle East Respiratory Syndrome | Coronavirus | CDC. Retrieved September 1, 2017, from https://www.cdc.gov/coronavirus/MERS/index.html

de Groot, R. J., Baker, S. C., Baric, R. S., Brown, C. S., Drosten, C., Enjuanes, L., ... Ziebuhr, J. (2013). Middle East Respiratory Syndrome Coronavirus (MERS-CoV): Announcement of the Coronavirus Study Group. Journal of Virology, 87(14), 77907792. https://doi.org/10.1128/JVI.01244-13

Diekmann, O., \& Heesterbeek, J. A. P. (2000). Mathematical Epidemiology of Infectious Diseases: Model Building, Analysis and Interpretation. Wiley Series. John Wiley \& Sons, Inc.

Diekmann, O., Heesterbeek, J. A. P., \& Roberts, M. G. (2010). The construction of nextgeneration matrices for compartmental epidemic models. Journal of The Royal Society Interface, 7(47), 873-885. https://doi.org/10.1098/rsif.2009.0386

Liu, H., Kuang, Y., Jackiewicz, Z., Lanchier, N., Smith, H., \& Thieme, H. (2013). Spatial Spread of Rabies in Wildlife (Doctoral Dissertation). ASU Library, Arizona State University. Retrieved from https://repository.asu.edu/items/20921

Murray, J. D. (2002). Mathematical Biology: I . An Introduction, Third Edition. Interdisciplinary Applied Mathematics (Vol. 17). New York: Springer. https://doi.org/10.1086/421587

Murray, J. D. (2003). Mathematical Biology II: Spatial Models and Biomedical Applications. Interdisciplinary Applied Mathematics (Vol. 18). New York: Springer. https://doi.org/10.1007/b98869

Strauss, W. A. (2008). Partial Differential Equations: An Introduction, Second Edition. New Jersey: John Wiley \& Sons, Ltd.

WHO. (2017). Middle East respiratory syndrome coronavirus (MERS-CoV) - United Arab Emirates. Retrieved December 26, 2017, from http://www.who.int/csr/don/22december-2017-mers-cov-united-arab-emirates/en/ 